\title{
A 180,000 years sedimentation history of a perialpine overdeepened glacial trough (Wehntal, N-Switzerland)
}

\author{
Flavio S. Anselmetti - Ruth Drescher-Schneider • \\ Heinz Furrer · Hans Rudolf Graf · Sally E. Lowick • \\ Frank Preusser • Marc A. Riedi
}

Received: 29 June 2009/ Accepted: 3 March 2010/Published online: 25 November 2010

(C) Swiss Geological Society 2010

\begin{abstract}
A 30 m-deep drill core from a glacially overdeepened trough in Northern Switzerland recovered a $\sim 180$ ka old sedimentary succession that provides new insights into the timing and nature of erosion-sedimentation processes in the Swiss lowlands. The luminescencedated stratigraphic succession starts at the bottom of the core with laminated carbonate-rich lake sediments reflecting deposition in a proglacial lake between $\sim 180$ and $130 \mathrm{ka}$ ago (Marine Isotope Stage MIS 6). Anomalies in geotechnical properties and the occurrence of deformation structures suggest temporary ice contact around $140 \mathrm{ka}$. Up-core, organic content increases in the lake deposits
\end{abstract}

Editorial handling: M. Fiebig.

F. S. Anselmetti ( $\square)$

Eawag, Swiss Federal Institute of Aquatic Science

and Technology, Surface Waters, Üeberlandstrasse 133,

8600 Dübendorf, Switzerland

e-mail: flavio.anselmetti@eawag.ch

R. Drescher-Schneider

Institut für Pflanzenwissenschaften, Karl-Fanzen-Universität

Graz, Holteigasse 6, 8010 Graz, Austria

H. Furrer

Paläontologisches Institut und Museum, Universität Zürich,

Karl Schmid-Strasse 4, 8006 Zürich, Switzerland

H. R. Graf

Matousek, Baumann \& Niggli AG, Mäderstrasse 8,

5401 Baden, Switzerland

S. E. Lowick · F. Preusser

Institut für Geologie, Universität Bern, Baltzerstrasse $1+3$, 3012 Bern, Switzerland

M. A. Riedi

Susenbühlstrasse 41, 7000 Chur, Switzerland indicating a warming of climate. These sediments are overlain by a peat deposit characterised by pollen assemblages typical of the late Eemian (MIS 5e). An abrupt transition following this interglacial encompasses a likely hiatus and probably marks a sudden lowering of the water level. The peat unit is overlain by deposits of a cold unproductive lake dated to late MIS 5 and MIS 4, which do not show any direct influence from glaciers. An upper peat unit, the so-called «Mammoth peat», previously encountered in construction pits, interrupts this cold lacustrine phase and marks more temperate climatic conditions between 60 and $45 \mathrm{ka}$ (MIS 3). In the upper part of the core, a succession of fluvial and alluvial deposits documents the Late Glacial and Holocene sedimentation in the basin. The sedimentary succession at Wehntal confirms that the glaciation during MIS 6 did not apparently cause the overdeepening of the valley, as the lacustrine basin fill covering most of MIS 6 is still preserved. Consequently, erosion of the basin is most likely linked to an older glaciation. This study shows that new dating techniques combined with palaeoenvironmental interpretations of sediments from such overdeepened troughs provide valuable insights into the past glacial history.

Keywords Pleistocene - Glacial erosion · Proglacial sedimentation - Alps · Luminescence dating · Drillholes

\section{Introduction}

Quaternary glaciations had an important impact on the landscape morphology in the perialpine region. Ice masses that moved from the Alps onto the lowlands caused substantial bedrock erosion and re-deposition of unconsolidated sediment, forming a variety of glacial landforms such as 
moraine ridges and glacial basins. From seismic data and from several deep drill holes, it is known that a variety of palaeo-valleys have been deeply incised into the molasse bedrock in the Swiss Alpine Foreland (Jordan et al. 2008). These features are referred to as overdeepened troughs and reach a depth of up to $300 \mathrm{~m}$ below the surface of the present valley bottom, for example in the Aare Valley south of Bern (Schlüchter 1979) and in northern Switzerland (e.g., Schindler 1985; Keller and Krayss 1999).

The sediment fills of such overdeepened basins are of eminent importance as groundwater reservoirs and, more recently, glacial overdeepening gained attention in the context of the Swiss radioactive waste disposal program. Until now, the question of how and when these structures were formed remains largely unsolved. The poor knowledge of the timing of these erosional-depositional processes is due to the fact that the Early and Middle Quaternary glaciation history of the Swiss lowlands is so far poorly constrained, due mainly to the lack of suitable dating methods.

The oldest dated sediment sequence of an overdeepened trough in the Swiss lowlands was drilled at the Thalgut site on the southern margin of the Aare Valley near Thun (Schlüchter 1989a, b). At this site, a basal glacial unit that overlies bedrock at $147 \mathrm{~m}$ depth is overlain by lacustrine deposits that bear an interglacial pollen assemblage characterised by a dominance of Fagus (beach, up to 58\%) and a prominent presence of Pterocarya (wingnut, up to $7 \%$; Welten 1988). This pollen assemblage is considered characteristic of the Holsteinian Interglacial (e.g., Beaulieu et al. 2001). The erosional period at the base of the Thalgut sequence is likely caused by the glaciation preceding the Holsteinian Interglacial. The age of the Holsteinian, however, is controversially discussed in the literature. While some studies favour a correlation with Marine Isotope Stage (MIS) 11 ( $430 \mathrm{ka}$; e.g., Beaulieu et al. 2001), dating of peat from the type region in northern Germany by U/Th methodology indicates a correlation with MIS 9 ( $330 \mathrm{ka}$; Geyh and Müller 2005). This correlation is also favoured by the German Commission for Quaternary Stratigraphy (Litt et al. 2007). Following this chronological correlation of the Holsteinian, the likely age of erosion at the base of the Thalgut sequence is attributed to a glaciation that occurred during MIS 10 ( 350 ka).

Age constraints for another overdeepened site in the Aare Valley are available from drill cores taken near Meikirch NW of Bern that reached a depth of 112 m (Welten 1982, 1988). Similar to Thalgut, lacustrine sediments are found overlying a basal glacial unit, although the basement was not reached. Luminescence dating and re-interpretation of the original pollen data imply that the sequence is younger than the interglacial of Thalgut (=Holsteinian) and mainly correlates with MIS 7 ( 250-190 ka, Preusser et al. 2005).
The infilling sediments of the Meikirch basin therefore most likely postdate an erosional phase that occurred during a glaciation in MIS 8 ( 280-250 ka).

In the above context, it has also to be kept in mind that sedimentary fillings only provide a minimum age for the formation of troughs. Glacial advances usually follow preexisting valleys, often formed by previous glaciations, as the poorly consolidated sediment fills of those troughs provide easily eroded pathways. As a consequence, the formation of overdeepened troughs and their sediment infill is most probably the product of numerous repetitive glaciations. However, there are very few well documented sedimentary records available yet to statistically evaluate the age of the erosional events.

To date, a major uncertainty concerns the questions of whether or not the Swiss lowlands have been glaciated during MIS 6 ( 190-130 ka) and whether substantial overdeepening may have occurred during this time. While for many areas in other mountain ranges substantial glaciations are usually expected for this period, which is considered to represent the Rissian/Saalian glaciation (cf. Litt et al. 2007; Habbe et al. 2007), Schlüchter (1988a) concluded on the basis of the Thalgut and Meikirch sites that Swiss glaciers did not reach beyond the margin of the Alps during MIS 6. To solve this controversy, more drill holes will be necessary to evaluate potential periods of glacial overdeepening, to document the processes and timing of sedimentation and to investigate synchronicities in various glacial valleys along the alpine foreland.

In this study, we present the results of a drilling campaign recovering the upper $30 \mathrm{~m}$ of the sediment succession of the overdeepened trough in the Wehntal (Zürich lowlands, Northern Switzerland; Figs. 1, 2, CHcoordinates $670^{\prime} 700 / 262^{\prime} 175$ ). The area is already known for its famous Niederweningen site with its rich fossil vertebrate record found in peat deposits encountered in shallow holes and construction pits of a few meters depth (cf. Furrer et al. 2007). The drill site is situated close to this mammoth site, just about $20 \mathrm{~km}$ northwest of Zürich. Here, we focus on the sedimentology and age of deposits below the so-called «Mammoth peat». The overdeepened basin of Wehntal is exceptional as it is situated beyond the limits of the Last Glacial Maximum (LGM) moraine ridges and not located in one of the major Alpine drainage valleys (Fig. 1). As a consequence, the limited effect of erosion has left a relative complex sequence of pre-LGM sediments in the subsurface that provide a critical opportunity for reconstructing the older glacial history.

The drill site is located immediately to the north of the major Lägeren thrust that was active during detachment and folding of the Jura Mountains (Fig. 2). While the slope to the south of the valley is mainly composed of Jurassic and Neogene bedrock of the easternmost Jura anticline, the 


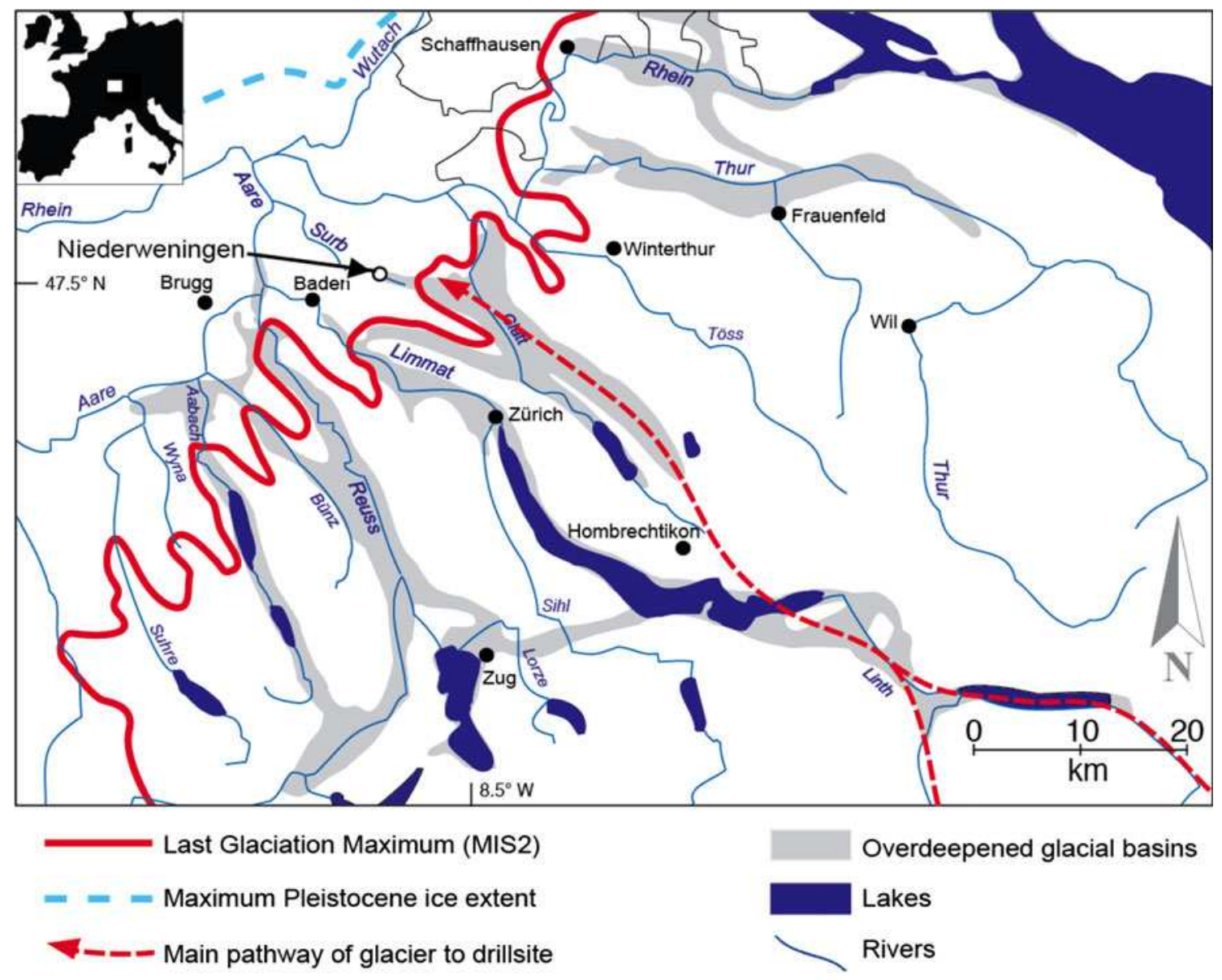

Fig. 1 Location of Niederweningen drill site in Northern Switzerland (black arrow). Maximum ice extent of the Last Glaciation (MIS 2 ) and of the Pleistocene maximum are indicated. Note locations of

northern slope exposes only Neogene molasse bedrock (Bitterli-Dreher et al. 2007). The drill site is located $\sim 4 \mathrm{~km}$ down-valley of the LGM terminal moraines that are found near the village of Sünikon-Steinmaur (Fig. 2).

Previous investigations of the Quaternary deposits of the area by Welten (1988) and Schlüchter (1988b, 1994) identified two peat horizons (Fig. 3) with ages that have been controversially discussed for some time. More recent investigations were able to demonstrate that the upper peat («Mammoth peat»), which is found at about $4 \mathrm{~m}$ depth, has an age of $\sim 45 \mathrm{ka}$ (Hajdas et al. 2007, 2009; Preusser and Degering 2007) and represents a period of moderate climatic conditions during the Middle Würmian (Coope 2007; Drescher-Schneider et al. 2007; Tütken et al. 2007). The lower peat, only encountered in three shallow drill holes from the 1980s at a depth of $\sim 10 \mathrm{~m}$, has been correlated to the Last Interglacial (Eemian, MIS 5e) on the basis of its pollen assemblages (Welten 1988). Below this peat, Schlüchter (1988b) and Welten (1988) described lacustrine deposits that are poor in pollen in their upper part. The modern lakes and filled overdeepened glacial basins. Inset shows location of Fig. 1 within Europe

lower part is characterised by an interglacial pollen assemblage with 10-20\% Abies, 10\% of both Alnus and Corylus as well as $4 \%$ of mixed oak taxa. Buxus is present with some $0.6 \%$ together with Carpinus and Fagus. 25-35\% of pollen of Picea and Pinus indicate that this section represents probably the final part of a pre-Eemian interglacial period. Unfortunately, none of the previous drill holes reached bedrock.

The previous investigations imply that a complex sedimentary sequence exists in Wehntal, especially below the lower peat horizon that has been attributed to the Last (Eemian) Interglacial (Welten 1988). Unfortunately, no detailed sedimentological description is available for the recovered cores nor have any proxy other than pollen been used for reconstructing the palaeo-environmental conditions. A further drawback is that numerical dating of sediments beyond the limits of radiocarbon was not possible at that time. The previous investigations found no evidence for input of glacial material between the Eemian and the lower lacustrine interglacial, which is, however, 
Fig. 2 Simplified geologic map of the Wehntal with the location of the drill site in the vicinity of the various mammoth sites in Niederweningen (red arrow). Coordinates are indicated in Swiss grid

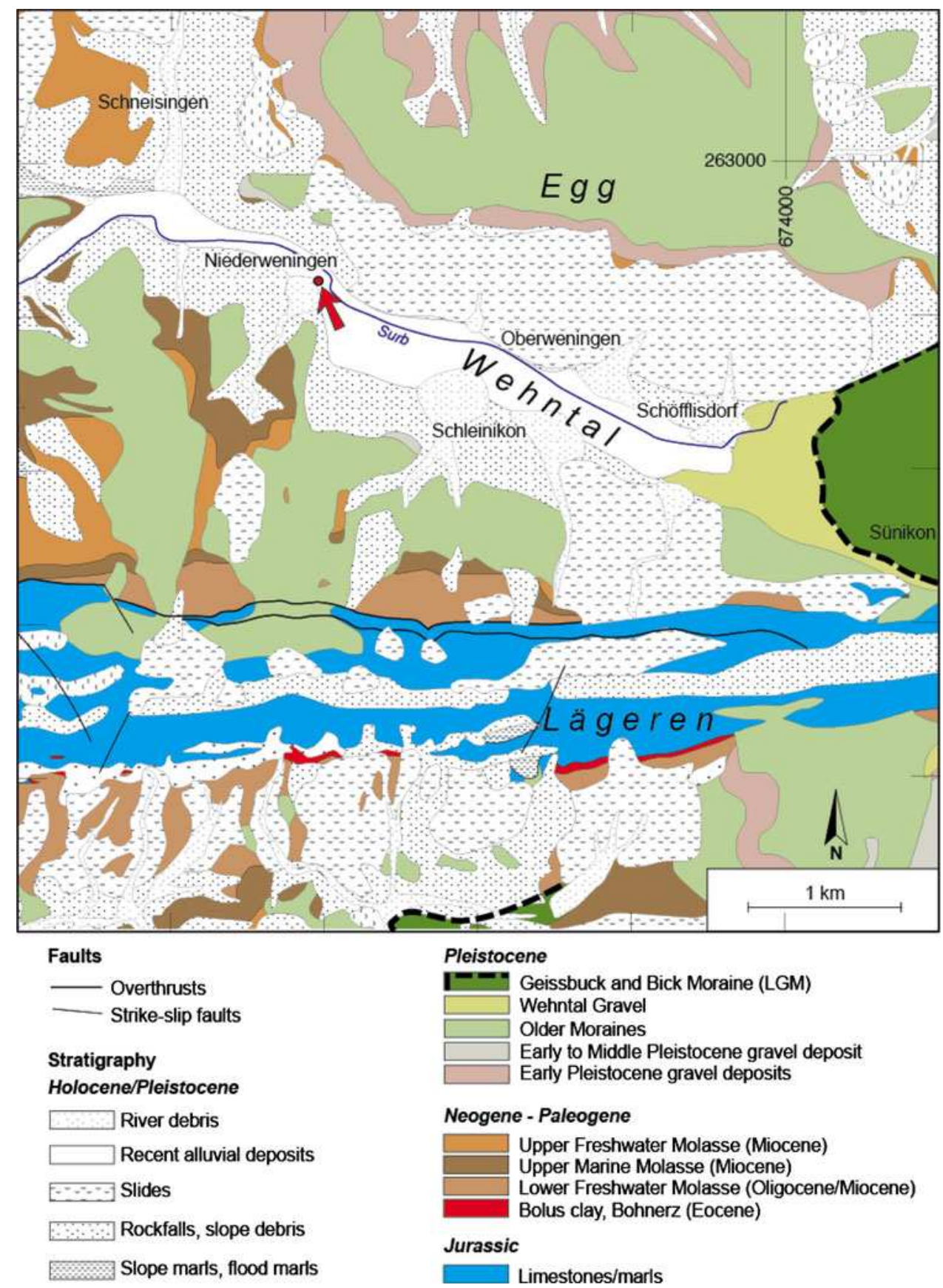

fragmentary and hence difficult to correlate. Nevertheless, the geological findings apparently support the interpretation of Schlüchter (1988a) that MIS 6, the period just preceding the Eemian, does not represent a very extensive (>LGM) glaciation in Switzerland.

In the present study, a $30 \mathrm{~m}$ long composite core taken near Niederweningen in late 2007 is investigated with sedimentological, geochemical and geotechnical techniques. Its age is constrained by palynostratigraphy and luminescence dating and the combination of these data provides new and crucial insights into the glaciation history of Northern Switzerland.

\section{Methods}

\section{Coring}

The technical set-up of the drilling was designed to recover the best possible quality sediment cores. For this reason, initial drilling (Hole NW1/07, 0-13.3 m) was carried out using a triple core-barrel by forcing the sediments directly into transparent liners of $7 \mathrm{~cm}$ diameter. This technique requires a certain addition of water or compressed air during drilling. Adjusting the water supply was challenging for these particular sediments and during the initial stage of 


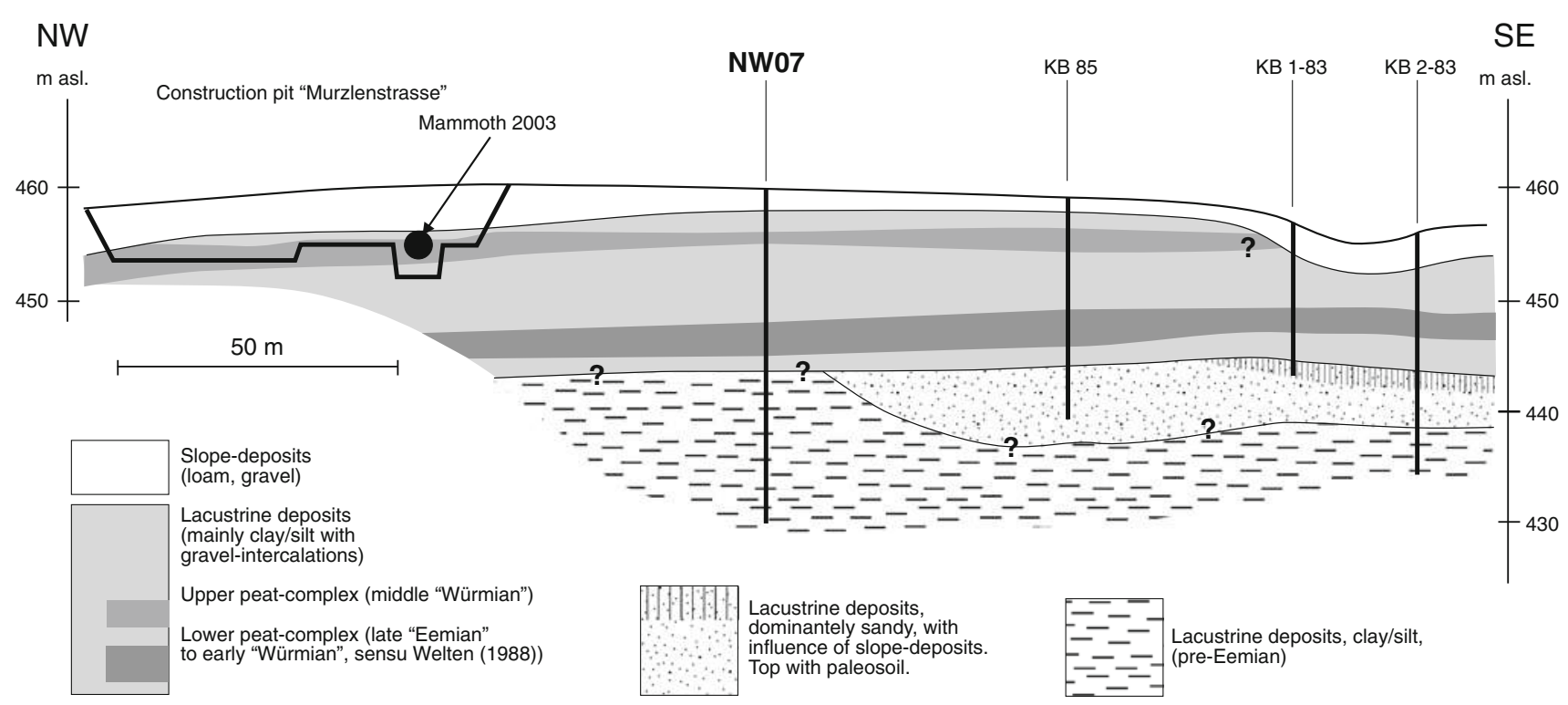

Fig. 3 Geological section (Profile 1) through the construction pit 2003 and the drill holes at Niederweningen (locations of sites are near drillsite shown in Fig. 2; modified after Furrer et al. 2007)

the drilling campaign, parts of the cored sediments were washed out and lost, but eventually the optimal adjustment for water supply was established. While drilling the lower peat layer, the core equipment heated up from mantle friction, so that the plastic liners started to melt causing significant loss of core material. As the peat has been a major target of the project, a second drillhole was started using compressed air (Hole NW2/07, 0-17.27 m). This technique was not ideal either as air pressure caused blowout of peat and sediment particles. Our experience implies that the triple core-barrel technique is not very suitable for the Wehntal sediment sequence, in particular for the peat horizon. Finally, a third core was recovered (NW3/07, 11-30.25 m) using a single core-barrel technique that provided optimal core quality with a large diameter. The peat recovery, however, remained slightly problematic as the peat sections could only be removed from the core barrel with great difficulty causing minor loss of sediments. Despite these difficulties, the overlap between the different cores was easily reconstructed as overall recovery was good and the drill holes were positioned only $3 \mathrm{~m}$ apart. As a consequence, a composite section could be defined without gaps at the splice points (see next section).

Petrophysics, sedimentology, geochemistry

The cores recovered in plastic liners were scanned before opening with a GEOTEK Multisensor Core Logger (MSCL) every $5 \mathrm{~mm}$ for p-wave velocity, magnetic susceptibility and gamma-ray-based wet bulk-density $\left({ }^{137} \mathrm{Cs}\right.$ source). $\mathrm{P}$-wave velocity measurements could not be used, because non-fullyfilled core liners did not allow propagation of the ultrasonic wave through the core. Cores were then split and digitally photographed. The cores that were extruded into boxes (NW3/07) could not be measured with the MSCL; their top few $\mathrm{cm}$ were sliced off in order to prepare an undisturbed sediment section for photographs and descriptions. The prepared surfaces were then analyzed every $40 \mathrm{~cm}$ for shear strength with a manual vane shear device (Eijkelkamp).

Cores were described macroscopically and lithotypes and stratigraphic units were defined. Smear slides were prepared to identify major constituents. Every $10-40 \mathrm{~cm}$, samples were taken for geochemical analysis. Inorganic carbonate and total organic carbon (TOC) were determined with a coulometer, acidification module and an autosampler/furnace (UIC-INC). Grain size analyses were performed laseroptically with a Malvern Mastersizer.

All results are reported in a composite depth scale that reflects the merging of the best sections of all three cores (see Fig. 4, left side). The transitions between the individual cores were fixed along prominent horizons that stand out visually and by their strong contrast in petrophysical properties. Hole NW2/07 (used in the composite section between 12.8 and $17.0 \mathrm{~m}$ ) showed coring disturbances in the upper part and a resulting depth offset when compared to NW1/07 and NW3/07. As a consequence, its depth values were reduced by $0.5 \mathrm{~m}$ before it was merged with the composite section.

\section{Pollen analysis}

For palynological investigations, about 200 samples (2-3 $\mathrm{cm}^{3}$ each) were taken from cores NW2/07 and NW3/ 07 at about $2-20 \mathrm{~cm}$ intervals. From this set of samples, 


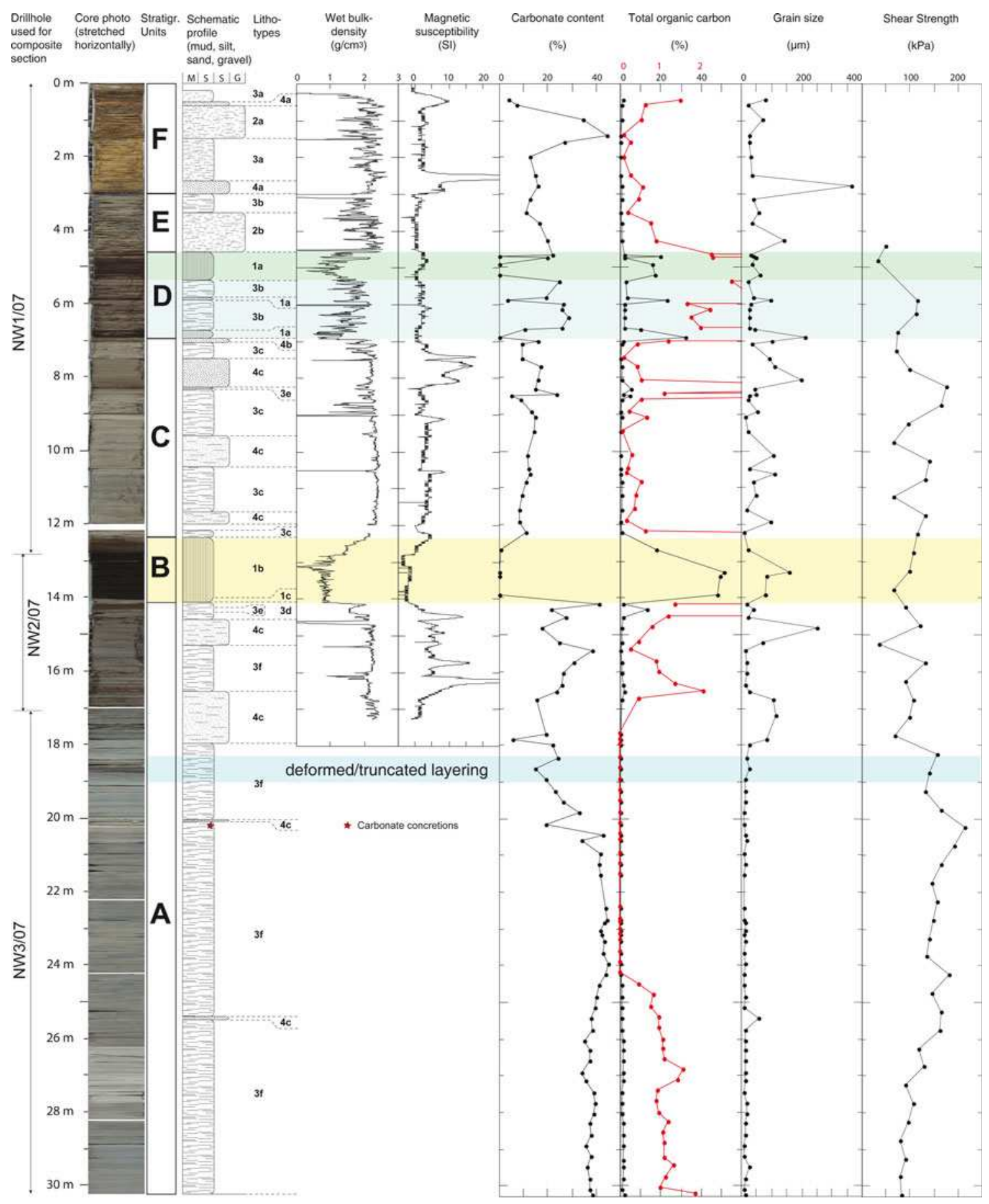

Fig. 4 Core photograph of the complete composite section with lithologic $\log$ (grain-size coded: MSSG = mud, silt, sand, gravel), stratigraphic units, wet bulk-density and magnetic susceptibility (down to $17.5 \mathrm{~m}$ in Cores NW1 and NW2/07), grain size and shear

strength values as well as carbonate and total organic carbon content. The peat layers are indicated by green and yellow shading. TOC is plotted in two scales (black (0-20) and red (0-3) dots, respectively) for better low-variability changes

$\sim 100$ samples were prepared for analyses using hydrofluoric acid (to remove inorganic material) followed by acetolysis (for removing organic matter). For each sample, 500 pollen grains were analysed and counted at a magnification of $400 \times$ to $1,000 \times$. The results are presented in the form of a percentage pollen diagram. Included in the pollen

sum $(100 \%)$ is the pollen of all trees, shrubs and upland herbs. The spores of ferns and mosses and the NPP (nonpollen palynomorphs like algae and stomata) are expressed referring to the pollen sum. The local pollen assemblage zones are defined in the traditional (not numerical) way according to Birks (1973). 
Luminescence dating

Luminescence dating uses a light sensitive latent signal in quartz and feldspar grains that is induced during burial by naturally occurring radioactivity. During sediment transport, when the grains are exposed to daylight, the latent signal is erased. The event dated by luminescence is hence the time of sediment deposition. A recent detailed review on the methodological aspects of luminescence dating has been provided by Preusser et al. (2008). For dating, two values have to be determined, first, the dose absorbed during burial $\left(D_{\mathrm{e}}\right)$ and, second, the dose rate $(D)$.

For this study, sediment half-cores (7 cm diameter) were taken to the red-light laboratory in Bern where the outer $\sim 1 \mathrm{~cm}$ of sediment was removed as it may have been exposed to light during drilling, transport and storage. Only homogenous parts of the cores without cracks were chosen for dating. The sample depths are given in Table 1. The removed outer part of the core material was used for measuring the concentration of dose rate relevant elements (K, Th, U) by high-resolution gamma spectrometry (cf. Preusser and Kasper 2001) and for the determination of moisture content and water up-take capability (Lowick and Preusser 2009). The inner part of the core material was chemically pre-treated by $\mathrm{HCl}, \mathrm{H}_{2} \mathrm{O}_{2}$ and $\mathrm{Na}$-Oxalate to remove carbonates, organic matter and clay minerals that may interfere with correct $D_{\mathrm{e}}$ determination. The fraction 4-11 $\mu \mathrm{m}$ was enriched by settling using Stokes' law and subsequently divided into two parts. While the first fraction was processed in unchanged conditions, the second was etched in $30 \% \mathrm{H}_{2} \mathrm{SiF}_{6}$ for 1 week to remove feldspar. The success of this treatment was verified by IR stimulation (cf. Mauz and Lang 2004). From each fraction, hereafter called the (1) polymineral and (2) quartz fraction, a series of aliquots were produced that each contained about $2 \mathrm{mg}$ of sample material.

The modified single-aliquot regenerative (SAR) protocol was used for $D_{\mathrm{e}}$ determination (cf. Murray and Wintle 2000, 2003; Wallinga et al. 2000; Preusser 2003; Wintle and Murray 2006). The polymineral fraction was stimulated by IR diodes for $300 \mathrm{~s}$ at room temperature and infrared stimulated luminescence (IRSL) was detected through a combination of a Schott BG 39 and a $410 \mathrm{~nm}$ interference filter (L.O.T.-Oriel). The quartz fraction was stimulated using blue diodes for $60 \mathrm{~s}$ and optically stimulated luminescence (OSL) emissions were detected through a Hoya U340 filter. Preheat conditions were chosen according to the results of preheat, dose recovery and thermal transfer tests. A preheat at $230^{\circ} \mathrm{C}$ for $10 \mathrm{~s}$ was applied prior to all OSL measurements (preheat plateau from $230-270^{\circ} \mathrm{C}, 101 \%$ dose recovery, $0.36 \%$ recuperation). For polymineral fine grains, preheating at $290^{\circ} \mathrm{C}$ for $10 \mathrm{~s}$ (samples NWG $1-5$ ) and at $270^{\circ} \mathrm{C}$ for $10 \mathrm{~s}$ (samples

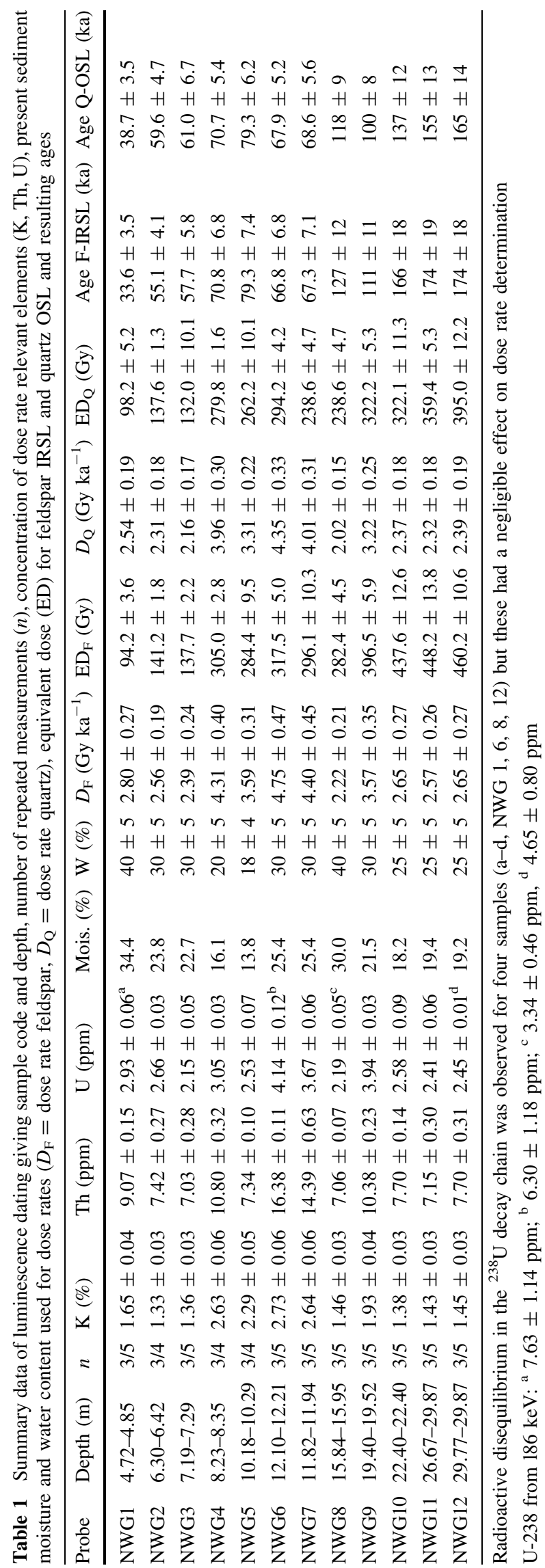


NWG 6-12) was used. Due to the excellent reproducibility of the samples, a relatively small number of aliquots were measured (quartz: 5 , polymineral: 3 ).

The results of gamma spectrometry and measurement of sediment moisture are summarised in Table 1. For four of the samples some evidence for disequilibrium in the Uranium decay chain was identified (samples NWG 1, 6, 8, 12; Table 1) using the approach described by Zander et al. (2007). Different scenarios of disequilibrium have been modelled using ADELE software (Kulig 2005) but, as already pointed out by Preusser and Degering (2007) for samples from the mammoth site, the effect on age determination is negligible compared to other uncertainties. With regard to water content, the measured moisture was used as a guideline together with some uncertainty to account for loss of water during drilling and subsequent storage. To account for the limited effect of alpha particles to induce a luminescence signal, $a$-values of $0.07 \pm 0.02$ (polymineral) and $0.04 \pm 0.01$ (quartz) were used. Cosmic dose rate was calculated for present depth and geographic position. Resulting ages in Table 1 are given for both the quartz (Q-OSL) and feldspar (polymineral; F-IRSL) fractions.

\section{Results}

\section{Physical properties}

Cores NW1/07 and NW2/07 were drilled and recovered in PVC liners, so that the wet bulk density and magnetic susceptibility could be measured every $5 \mathrm{~mm}$ down to a composite depth of $17.27 \mathrm{~m}$ (Fig. 4). Bulk density values usually scatter around $2.0 \mathrm{~g} \mathrm{~cm}^{-3}$, while the highest and most stable values of around $2.2 \mathrm{~g} \mathrm{~cm}^{-3}$ were obtained in the interval between 7.0 and $12.0 \mathrm{~m}$. These sections of generally high density values, which indicate high detrital content, are intercalated by three intervals where density values are much lower (4.6-5.36, 6.76-6.94 and $12.4-14.1 \mathrm{~m})$. In these sections, density values drop close to $1.0 \mathrm{~g} \mathrm{~cm}^{-3}$ with the interval below $12 \mathrm{~m}$ depth even reaching values below $1.0 \mathrm{~g} \mathrm{~cm}^{-3}$. As shown below, these low-density sections are characterised by a high content of organic matter.

Magnetic susceptibility values are generally low and vary between 0 and 5 SI units. Some peaks of elevated values occur, one at $2.54 \mathrm{~m}$ (99 SI), which is caused by a detrital gneiss-clast of $2 \mathrm{~cm}$ in diameter. Values of up to 40 SI units occur between 14 and $17 \mathrm{~m}$, where an increased number of opaque Fe-oxides were observed in the smear slides. A well-defined interval between 7.3 and $8.3 \mathrm{~m}$ depth is characterised by magnetic susceptibilities values of up to 16 SI-units, corresponding to a rather coarse-grained detrital lithology.
Shear strength values scatter in the section above $18 \mathrm{~m}$ between $\sim 50-150 \mathrm{kPa}$ increasing rather abruptly to values of $213 \mathrm{kPa}$ at $20.25 \mathrm{~m}$ (Fig. 4). Below this maximum in shear strength, values decrease gradually all the way to the bottom of the hole to $\sim 80 \mathrm{kPa}$ at $30.25 \mathrm{~m}$.

\section{Sedimentology, lithotypes, geochemistry}

On the basis of sedimentological descriptions, petrophysical and geochemical analysis, four lithotypes and various subtypes were defined. Table 2 summarizes the characteristics of these lithotypes, Fig. 4 shows their succession and Figs. 5 and 6 show representative core photographs.

Lithotype 1, termed peat s.l., is marked by dark-brown to black, very organic-rich lithologies with low densities, no diatoms, and variable amounts of plant material. Lithotype 1a has a higher degree of detrital constituents and thus a lower TOC content (15-30\%) and is classified as gyttia. Lithotypes $1 \mathrm{~b}$ and $1 \mathrm{c}$ are characterised by very high TOC values of $50 \%$ (causing densities below $1 \mathrm{~g} \mathrm{~cm}^{-3}$ ) and by a very compact and indurated fabric (peat s.s., e.g., Cyperaceae and moss peat). Lithotype 1c contains in addition large wood fragments.

Lithotypes 2-4 are dominated by detrital components and are classified by their dominant grain size and grouped into Lithotypes 2 (gravel), 3 (silts) and 4 (sands) with various subtypes based on their colour, grain size-spectra and organic constituents. In these lithotypes, densities are high and TOC is low. In general, the components consist mostly of detrital carbonate grains and gravels as well as quartz. Smear slide analysis indicates that biogenic components, such as diatoms, are absent, as are authigenically precipitated carbonates. The gravels of Lithotype 2a show a brownish-red colour, while Lithotype $2 \mathrm{~b}$ gravel are rather light grey. In some sections of Lithotypes 2-3, detrital plant fragments occur. Often, millimetre-scaled laminations or mottled fabrics occur (Fig. 6f, g). Deformed layers and unconformities characterise the sediments between $\sim 18.5$ and 19 m (Fig. 7).

\section{Stratigraphic units}

The $30.25 \mathrm{~m}$ long sedimentary composite section was grouped into six stratigraphic units that can be discerned by their characteristic successions of lithotypes (Units A-F; Fig. 4). The boundaries between these units are defined by the occurrence of prominent lithologic changes. The uppermost Units $F(0-3.0 \mathrm{~m})$ and $\mathrm{E}(3.0-4.6 \mathrm{~m})$ are partially gravel-bearing and consist of lithotypes $2 \mathrm{a}, 3 \mathrm{a}, 4 \mathrm{a}$ and $2 b, 3 b$, respectively. Unit $F$ shows at its top darker and organic-rich sections that reflect the modern soil formation. Underlying Unit D $(4.6-7.0 \mathrm{~m})$ consists at its top of a $55 \mathrm{~cm}$-thick prominent peat horizon (Lithotype 1a). The 
Table 2 Sedimentological, petrophysical and geochemical characteristics of lithotypes (and their sub-types)

\begin{tabular}{|c|c|c|c|c|}
\hline Lithotypes & $\begin{array}{l}\text { Wet bulk } \\
\text { density } \\
\left(\mathrm{g} / \mathrm{cm}^{3}\right)\end{array}$ & $\begin{array}{l}\text { Magnetic } \\
\text { susc. (SI) }\end{array}$ & $\begin{array}{l}\text { Carbonate } \\
(\%)\end{array}$ & $\begin{array}{l}\text { Total organic } \\
\text { carbon }(\%)\end{array}$ \\
\hline \multicolumn{5}{|l|}{ Lithotype 1: Peat s.l. } \\
\hline 1a: Dark-brown muddy-silty gyttia, few larger plant remains & $<1.5$ & $0-5$ & $0-3$ & $15-35$ \\
\hline 1b: Dark-brown to black muddy-silty peat s.s., few wood fragments, compacted & $\sim 1.0$ & $<1$ & $\sim 0$ & $\sim 50$ \\
\hline 1c: Dark brown muddy-silty peat s.s., with many large wood fragments & $<1.0$ & $0-1$ & $\sim 0$ & $\sim 50$ \\
\hline \multicolumn{5}{|l|}{ Lithotype 2: Gravels } \\
\hline 2a: Light-brown sandy-silty gravel, partly very coarse gravel & $\sim 2.0$ & $0-4$ & $34-45$ & $<1$ \\
\hline 2b: Light-grey sandy-silty gravel, partly very coarse gravel & $\sim 2.0$ & $0-1$ & $16-20$ & $<1$ \\
\hline \multicolumn{5}{|l|}{ Lithotype 3: Silts } \\
\hline 3a: Dark- to light-brown sandy silt, some pebbles & $\sim 2.0$ & $0-4$ gravel 99 & $12-27$ & $<1$ \\
\hline 3b: Light-grey, sandy silt, partly dark, organic-rich parts & $1.0-2.0$ & $0-2$ & $10-30$ & $<6$ \\
\hline 3c: Light-grey to green sandy silt with light-brown to white carbonate concretions & $\sim 2.3$ & $0-4$ & $5-26$ & $<2$ \\
\hline 3d: Light-grey to white silt, small plant remains and mollusc shells & $\sim 2.0$ & $0-14$ & $27-40$ & $<2$ \\
\hline 3e: Dark-brown organic-rich sandy silt, small plant remains & $1.5-2.0$ & $0-2$ & $5-22$ & $4-14$ \\
\hline 3f: Light-grey to light-green silt, carbonate concretions, organic-rich brown layers & & & $15-44$ & $<2$ \\
\hline \multicolumn{5}{|l|}{ Lithotype 4: Sands } \\
\hline 4a: Graded coarse sand, some large pebbles & $1.7-2-6$ & $0-9$ & $0-15$ & $<1$ \\
\hline 4b: Dark gray silty sand, with plant remains & $1.5-2-0$ & $0-2$ & $\sim 16$ & $<2$ \\
\hline 4c: Silty fine-medium sand, carbonate concretions, plant remains & $2.0-2.3$ & $2-17$ & $5-38$ & $<5$ \\
\hline
\end{tabular}

Fig. 5 Core photographs with characteristic lithotypes $1-2$ : a Lithotype 1a (NW1/07, $4.95 \mathrm{~m}$ ); b Lithotype $1 \mathrm{~b}$ (NW2/ 07, $14.38 \mathrm{~m})$; c Sharp contact between Lithotype 1c (above) and $3 \mathrm{~d}$ (below) (NW2/07, $14.6 \mathrm{~m}$ ); d Lithotype 2a (NW1/ $07,1.37 \mathrm{~m})$; e Lithotype $2 \mathrm{~b}$ (NW1/07/4.27 m)
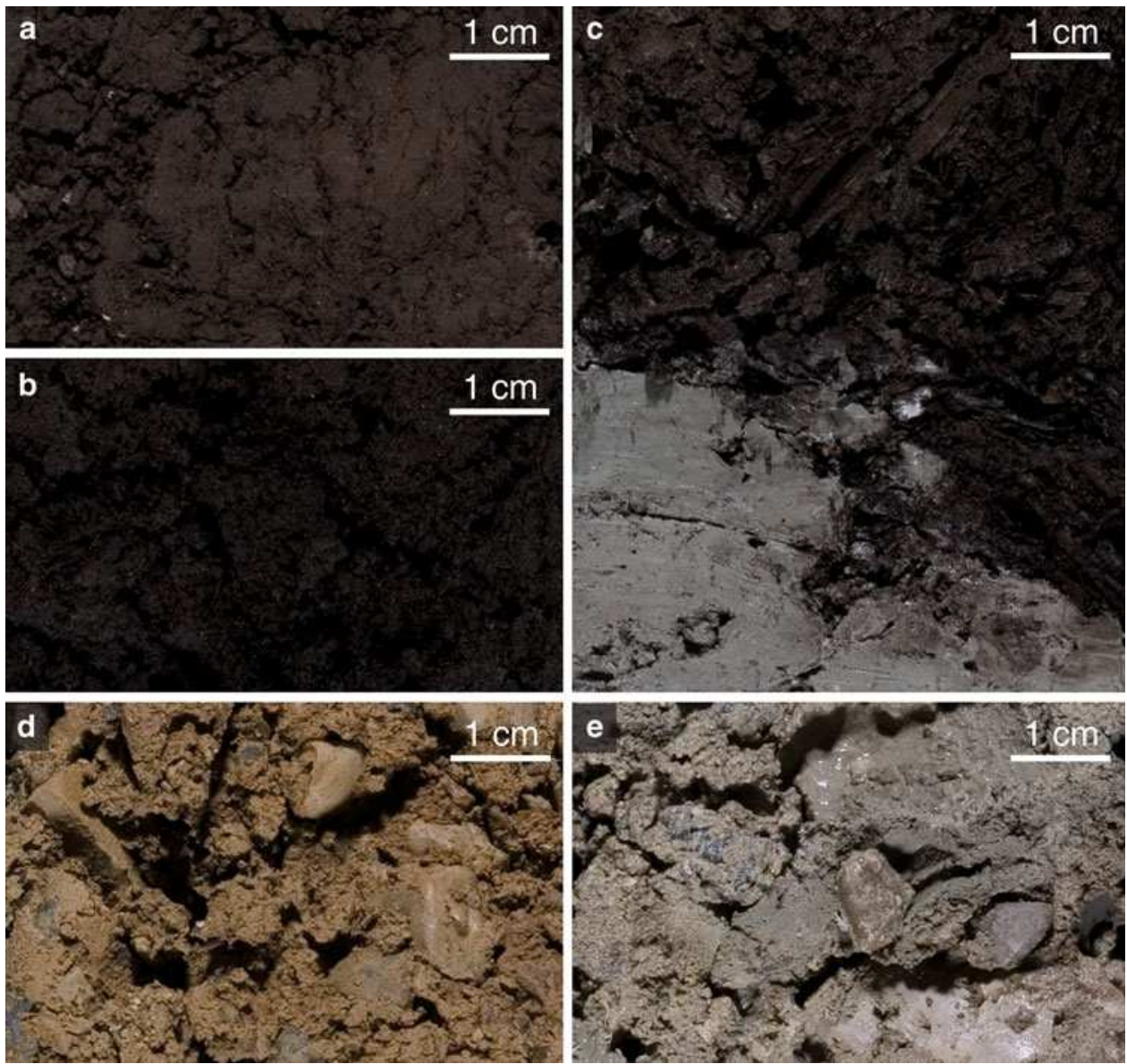

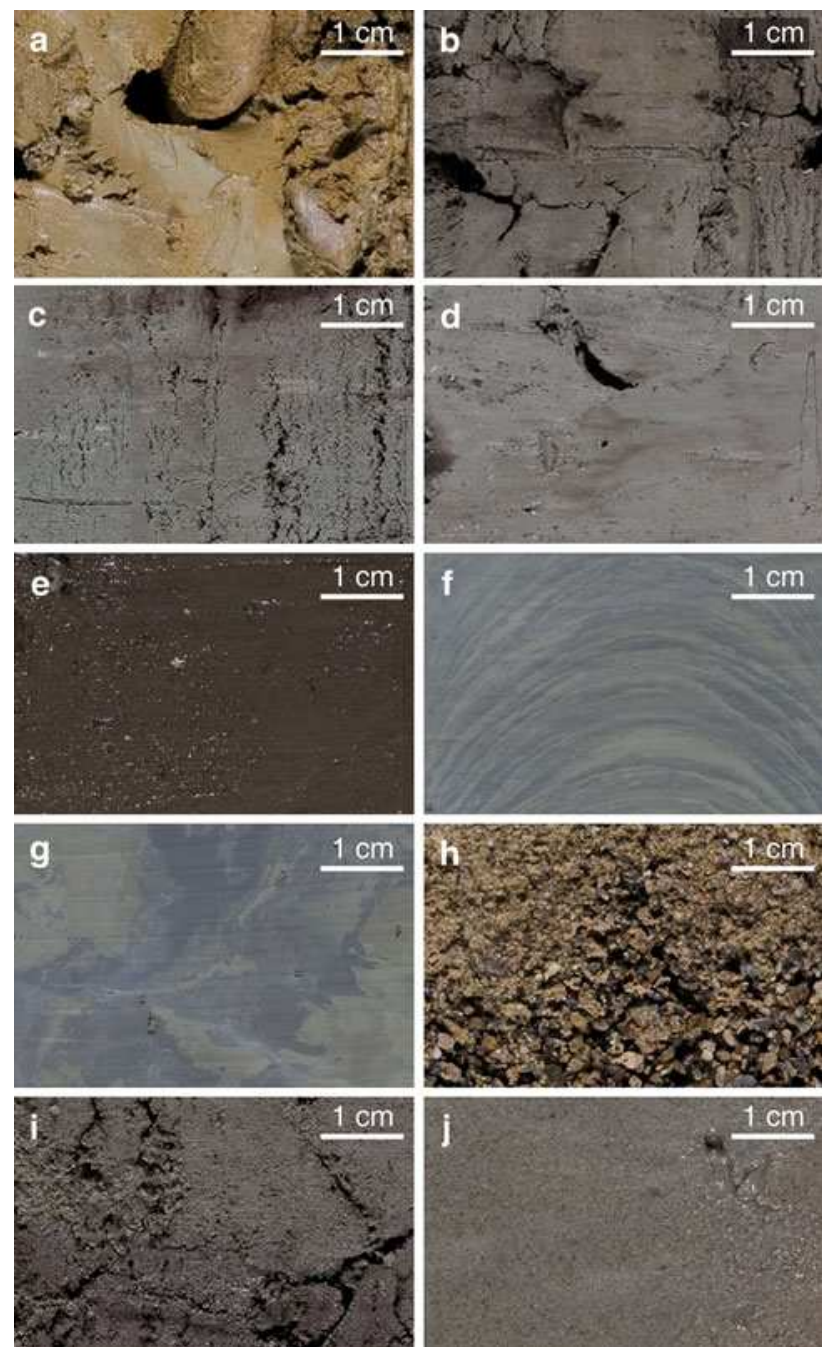

Fig. 6 Core photographs with characteristic lithotypes 3-4: a Lithotype 3a (NW1/07, 2.33 m); b Lithotype 3b (NW1/07, $6.35 \mathrm{~m}$ ); c Lithotype 3c (NW1/07, $11.36 \mathrm{~m})$; d Lithotype 3d (NW2/07, $14.68 \mathrm{~m})$; e Lithotype 3e (NW2/07, $14.82 \mathrm{~m})$; f Lithotype 3f (NW3/ 07, 22.53); g Lithotype 3f (NW3/07, $23.8 \mathrm{~m}$ ); h Lithotype 4a (NW1/ 07, $2.90 \mathrm{~m}$ ); i Lithotype 4b (NW1/07, $7.0 \mathrm{~m}$ ); j Lithotype 4c (NW1/ $07,7.95 \mathrm{~m})$

lower part of Unit D consists of silty sediments of Lithotype $3 \mathrm{~b}$ that include two thinner peaty layers. The down-core transition into mostly inorganic Unit C $(7.0-12.4 \mathrm{~m})$ is expressed by the switch to intercalations of predominantly Lithotypes $3 \mathrm{c}$ and $4 \mathrm{c}$ that show very little sediment structures or laminations. Carbonate content in Unit $\mathrm{C}$ ranges between 10 and 20\%. Underlying Unit B (12.4-14.1 m) is composed purely of peaty lithotypes $(1 \mathrm{~b}, 1 \mathrm{c})$. The upper boundary is formed by a rather gradual up-core transition from peat into the greenish silts of Unit $\mathrm{C}$, while the lower boundary of this peat unit is very sharp (Fig. 5c). The main Lithotype $1 \mathrm{~b}$ of the peat is composed of very fine plant debris. A thin layer at the base yields many wood fragments (Lithotype 1c).

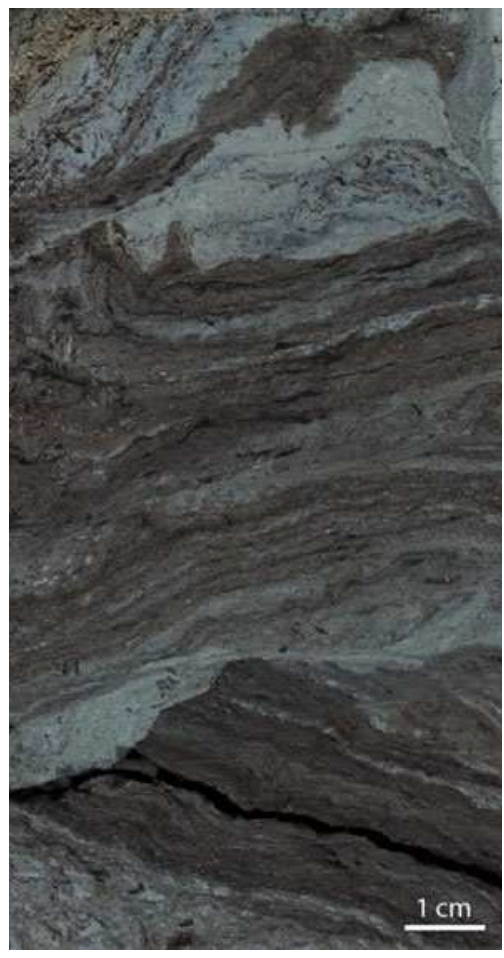

Fig. 7 Erosional unconformities and deformed sediments (NW3/07, between 18.58 and $18.75 \mathrm{~m}$ ). For interpretation see text

Below this sharp contact, Unit A (14.1-30.25 m) forms a thick succession of inorganic silt and sand deposits (mostly Lithotype 3f). The sediments are often laminated, some sections are homogenous. Carbonate content is higher as in Unit C, reaching 20-40\% from 14.1 to $20 \mathrm{~m}$ and increases to stable values around $35-45 \%$ below $20 \mathrm{~m}$. TOC averages $1-2 \%$, except for the interval from 18 to $24 \mathrm{~m}$, in which almost no organic material could be measured. Below $18 \mathrm{~m}$, the silty sediments are frequently mottled, indicating deformation of the original laminated sedimentary structures. The section between 18.5 and $19 \mathrm{~m}$ is characterized by tilted layers and erosional unconformities (Fig. 7).

\section{Biological remains}

The uppermost Units $\mathrm{F}$ and $\mathrm{E}$ are barren of any biological remains. The peaty levels of the underlying Unit $\mathrm{D}$ with its $55 \mathrm{~cm}$-thick prominent peat horizon at the top are very rich in plant debris. No vertebrate material was found. A sandy layer of Unit $\mathrm{C}$ contained an embedded small wood fragment of Ericaceae $(8.27 \mathrm{~m})$. The pure peat of Unit B is also composed of many plant remains. At $12.60 \mathrm{~m}$, a first test on chironomid larvae documented the presence of Pseudosmittia sp., together with bryozoan statoblasts of Plumatella-type (written communication O. Heiri, Utrecht). One small wood fragment at $12.94 \mathrm{~m}$ was identified as Pinus sylvestris. A thin 
Niederweningen NW3-07

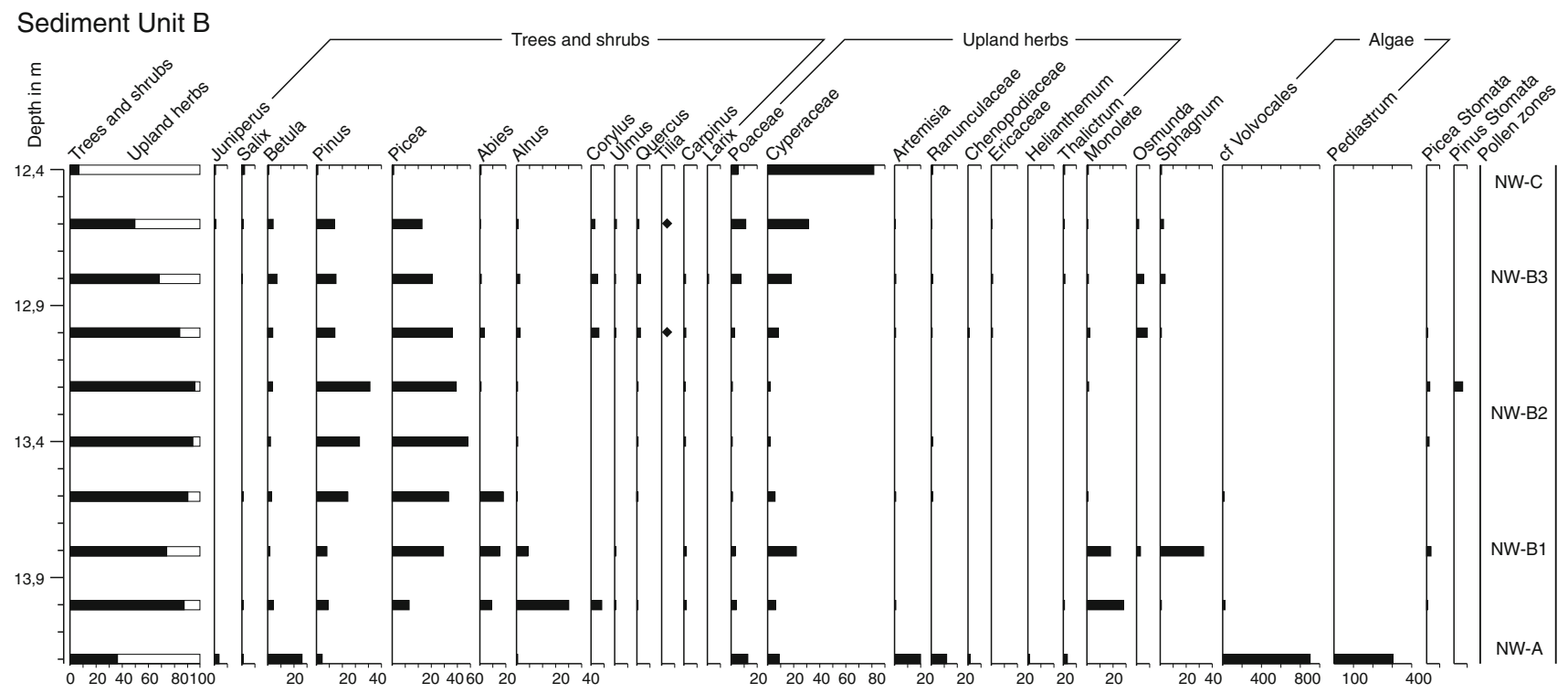

Fig. 8 Simplified pollen diagram of Unit B showing the percentages of the most important species

lenticular layer at the base of Unit B yielded many wood fragments $(14.05-14.15 \mathrm{~m})$, the biggest of which was $10 \mathrm{~cm}$ in length and could be identified as Alnus sp. (written communication W. Schoch, Langnau). The grey silt below the sharp contact to Unit A yields many characean-oogonoids (green algae) as well as some lacustrine gastropod and mussel shells (14.15-14.60 m). This horizon has a mottled structure and shows many plant roots with a diameter of 1-4 mm, cutting discordantly through the bedding planes. Samples from the deeper part of Unit A contain no macrofossils.

The presentation and discussion of the initial palynologic results is limited to stratigraphic Unit B (12.4-14.1 m) and its contacts to Units A and C. Five major pollen zones (PZ) are differentiated in the sequence presented in Fig. 8: the uppermost sample (PZ NW-C) represents the transition from the overlying lake sediments to the peat. The pollen flora is dominated by upland herbs (Cyperaceae). The low presence of Picea, Pinus, Juniperus and Salix and the absence of thermophilous species is interpreted to reflect rather colder climatic conditions. Pollen Zone NW-B3 is characterised by increasing values of Picea, the constant presence of Abies, Corylus, Ulmus, Quercus and-noticeable-Osmunda. Across the transition from pollen Zone NW-B3 to B2, the Cyperaceae peat with a small and irregular in-wash of silt and fine sand changes to a moss peat. In Zone NW-B2, forests still dominate the landscape, but they are composed mainly of Picea and Pinus. At the base, the peat changes from a moss peat to a material dominated by wood. Pollen Zone NW-B1 reflects a dense forest dominated by Picea and Abies in the upper part and by Alnus in the lower part. The oldest Zone $\mathrm{NW}$-A represents the pollen flora of the uppermost part of the proglacial lake sediments of underlying Unit A: low percentages of trees and shrubs (mainly Betula and Juniperus) and high values of upland herbs (Poaceae, Cyperaceae, Artemisia etc.) indicate a landscape covered by grassland and open birch forests with scattered Juniperus shrubs. The rich presence of algae (Volvocales, Pediastrum) demonstrates the lacustrine origin of the sediment.

Luminescence dating and age model

Luminescence ages calculated for the sediments from the Wehntal drill cores span from $\sim 35,000$ years $(=35 \mathrm{ka})$ in the upper to $\sim 170-180 \mathrm{ka}$ in the lowermost part of the composite section (Table 1; Fig. 9). Age estimates for quartz OSL and polymineral IRSL are generally consistent, which is interpreted as proving the reliability of $D_{\mathrm{e}}$ determination. Plotting an age/depth model reveals a continuous increase of OSL/IRSL ages with depth, with two exceptions. Samples between 8.2 and $12.2 \mathrm{~m}$ are not distinguishable within error limits, suggesting an increased sedimentation rate during this period. The second exception is sample NWG9 that gave age estimates lower than for the over- and underlying samples. Interestingly, this sample is located just below the horizon characterized by tilted layers and erosional unconformities. As a consequence, ages for this sample are interpreted as outliers and are not considered in the age model (Fig. 9).

Independent data confirming the luminescence-based age model are provided by the two peat horizons. On the basis of its stratigraphic position and pollen content, the peat of Unit D is correlated with the «Mammoth peat» that is dated to $\sim 45 \mathrm{ka}$ in its upper part (Hajdas et al. 2007; Preusser and 
Fig. 9 Top results of luminescence dating plotted versus depth (with stretched core photo and stratigraphic units indicated on left side). Black dots represent quartz OSL, red dots feldspars IRSL ages. Bottom correlation of the marine oxygen isotopes stages (MIS) as proxy for global ice volume $\left(\delta^{18} \mathrm{O}\right.$ of benthic foraminifera; Bassinot et al. 1994)

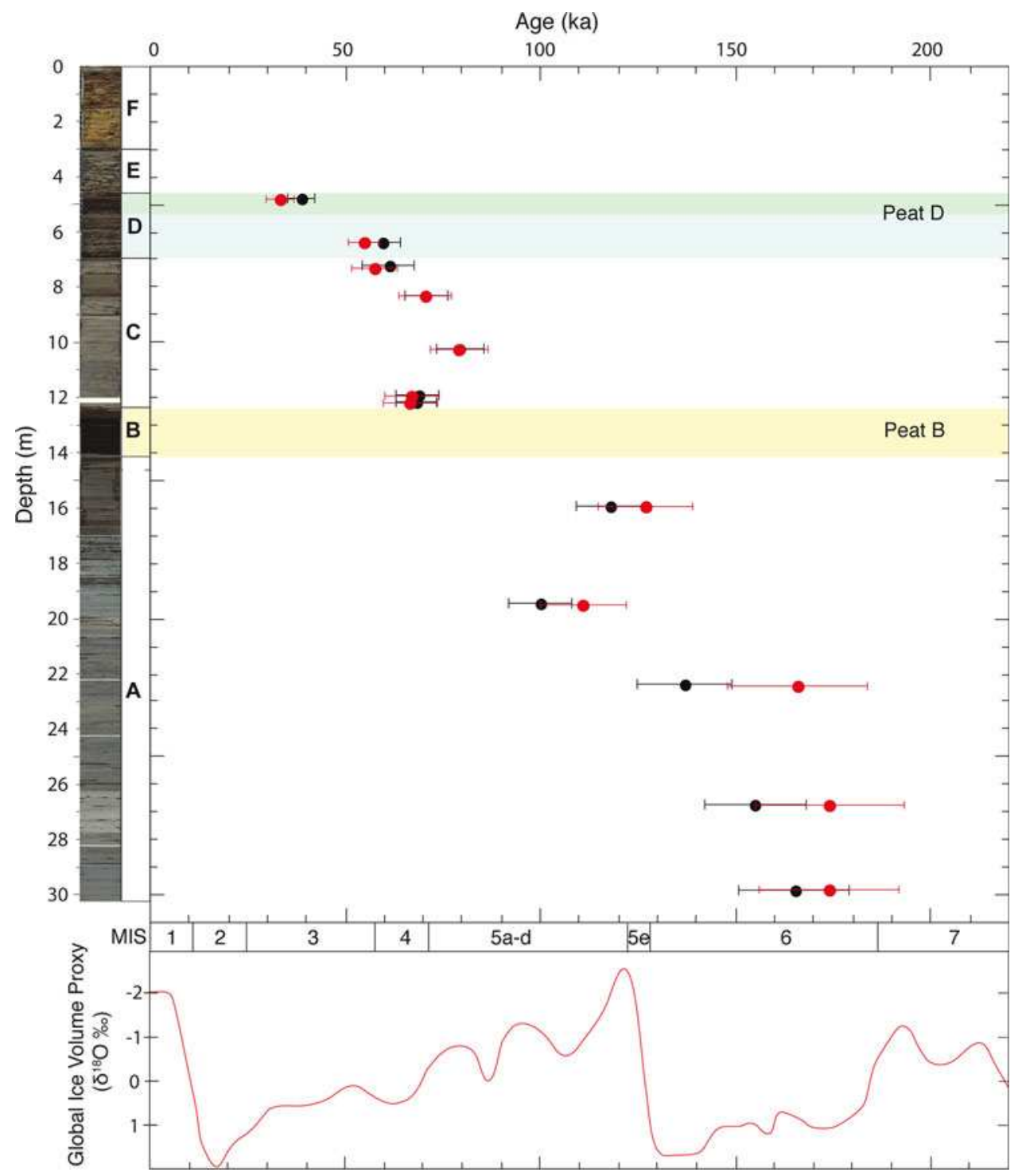

Degering 2007). The age for sediment from just above the horizon is dated to $38.7 \pm 3.5 \mathrm{ka}$ (NWG1, Q-OSL) and $33.6 \pm 3.5 \mathrm{ka}$ (F-IRSL). The sample from just below the peat of Unit B is dated to $118 \pm 9 \mathrm{ka}$ (Q-OSL) and $127 \pm 12 \mathrm{ka}$ (F-IRSL) and hence in agreement with the assumed age for the onset of the Eemian interglacial in the Alps $(\sim 130 \mathrm{ka}$, cf. Preusser 2004). All luminescence ages below the peat of Unit $\mathrm{B}$ are from sediments that are pollen-free, implying pronounced cold conditions during sedimentation. According to luminescence dating, this period corresponds to glacial MIS 6.

\section{Discussion}

Depositional environment of lithotypes

With the dark brown to black colour, the high organic content and the abundant plant remains, Lithotype 1 sediments were deposited in a marsh-swamp area and are classified as peat and gyttia deposits. Lithotypes $1 \mathrm{~b}$ and $1 \mathrm{c}$ show extremely high TOC values and no inorganic components, thus they lack any detrital input and were not affected by flood events. In contrast, the gyttia of Lithotype 1a has lower TOC values and contains inorganic detrital particles, implying that it was deposited in a shallow lake, pond or marsh area that frequently became inundated during floods.

The gravel layers of Lithotype 2 are interpreted as having been deposited in a fluvial environment as witnessed by the well-rounded character of the gravels. Most gravel consist of limestone that most likely originates from the Lägeren-anticline to the south of the drill-site (Figs. 1, 2), which is the easternmost expression of the folded Jura Mountains, where Jurassic limestone outcrops (Furrer et al. 2007). Lithotype 2 a contains a silty carbonate matrix that is also carbonate-rich, suggesting a purely «Lägeren» fluvial/ alluvial origin. The red-brownish colour reflects oxic 
conditions. The matrix of Lithotype $2 b$, in contrast, contains less carbonate and is grey-coloured, so that these gravels likely were deposited in the lacustrine environment in an area such as a delta or marginal area of a lake, where the gravel might have been brought in by strong runoff events and where the silty matrix has more a main-river or lacustrine origin.

The silty sediments of Lithotype 3 are interpreted as lake sediments that were deposited in a cold lake lacking any biologic productivity. This interpretation is supported by the lack of any biogenic particles such as diatoms and carbonate shells, by the absence of authigenic carbonates and by the low TOC values. The only exception to the postulated cold origin of these lacustrine sediments is the single interval of Lithotype $3 \mathrm{~d}$ that contains many characean-oogonoids as well as some gastropod and mussel shells. This layer was likely deposited in a shallow lake under warmer conditions as it is found today in ponds or shallow areas of lakes. The variable amount of sand reflects a sometimes more proximal or distal location in a generally rather quiet lacustrine environment. As is characteristic for proglacial lakes, the fine millimetre-scaled regular lamination, as seen in Lithotypes 3 of Unit A, likely represents classic detrital varves with the fine grained layer representing the calm winter conditions of a seasonally frozen lake (Blass et al. 2003; Anselmetti et al. 2007).

The sandy sediments of Lithotype 4 were deposited in a rather delta-proximal lacustrine environment during highenergy events when suspension-loaded river waters entered a proglacial lake and were distributed by underflow currents. The upward fining grain-size pattern, as found in Lithotype $4 \mathrm{a}$, is typical of such deposits, as are the reworked peat fragments of Lithotype $4 \mathrm{~b}$ that were eroded in the catchment and brought into the lake during flood events.

\section{Significance of deformation structures below $18.5 \mathrm{~m}$}

As described above, the section between 18.5 and $19.0 \mathrm{~m}$ is characterised by intense deformation structures (Fig. 7). These tilted layers with erosional unconformities reflect a mobilization of formerly concordant undisturbed lacustrine deposits. Only below this strong deformation zone does the mottled pattern of Lithotype $3 \mathrm{f}$ occur (Fig. 6g), which also indicates post-depositional deformation. A cryogenic deformation mechanism can be ruled out since the entire deformed section, as well as the under- and overlying sediments, consist of fine-grained lacustrine deposits lacking any signs of subaerial exposure. The observed deformation structures may be due either to (1) subaquatic mass movements, as induced by slope instabilities that may be triggered by earthquakes (Strasser et al. 2007), from (2) deformation caused by ploughing of grounded icebergs (Eyles et al. 2005), or from (3) ice-contact deformations when re-advancing glaciers override lacustrine deposits deforming them subglacially (Maltman et al. 2000, and references therein). Geotechnical analysis rather indicate ice-induced deformation ( 2 or 3 ), as slumping and sliding alone does not generally consolidate the down-going sediments. In fact, shear strength values sharply increase exactly at the interval with maximum deformation structures (Fig. 4), and reach a distinct maximum suggesting over-consolidation. These elevated values slowly decrease down-core and reach towards the base of the core at $30.25 \mathrm{~m}$ «normal» values as encountered above the deformation zone. However, it is expected that subglacial deformation would produce some coarse clastic components at the ice-contact surface, which are not observed in the drill cores. Instead, in and immediately above the deformed section, only fine-grained deposits with a grainsize up to fine-sand occur. Iceberg ploughing, in contrast, can deform deposits without leaving any coarse-grained sediments behind, but the $10 \mathrm{~m}$ thick interval of increased shear strength values seems rather large to be the result of only grounded 'clean' ice. On the basis of the existing data, the deformation structures can thus not be unequivocally related to a single process.

\section{Paleoenvironmental history}

\section{Unit A: between $\sim 180$ and $\sim 130 \mathrm{ka}$}

This unit, consisting mainly of laminated and mottled silts is almost free of organic and biogenic material and coarser layers, suggesting a depositional environment in the distal facies of a cold proglacial lake. The luminescence age for the base of the core is between $\sim 160$ and $180 \mathrm{ka}$ (Fig. 9; Table 1) so that this unit covers more or less most of MIS 6 . The proglacial lake was bounded to the southeast by the glacier front, providing melt waters and fine silty sediments («glacial milk») that were deposited in deeper lake areas by underflow deposits. To the northwest, i.e. down-valley, the lake may have been dammed by a terminal moraine or landslide. The few coarser layers probably reflect highdischarge events from the valley flanks or from the glacier, while the fine laminations are potentially annual layers (clastic 'glacial' varves) and document an annual freezing of the lake's surface with the finest layer deposited in winter. Carbonate content reaches values of over $40 \%$ reflecting a catchment dominated by carbonate rocks, which is not the case today, where the fluvial catchment of the Glatt valley is comprised of mostly siliciclastic molasse rocks. As discussed above, the observed sediment deformations at about $18.5 \mathrm{~m}$ and the increased shear strength values below, are intriguing and suggest either subaquatic slumping, iceberg ploughing or a temporary re-advance of the glacier, around $\sim 140 \mathrm{ka}$ ago. The two latter explanations are supported by 
other observations, i.e. the glacial varves and the high carbonate content, requiring both the Linth glacier to reach into the catchment. The sediment deformation were obviously only of moderate intensity, leading to only partial removal of the previously deposited lacustrine sediments.

Taking the entire evidence into account, we suggest that Unit A was deposited under the strong influence of an Alpine glacier that overcame the morphologic threshold at Hombrechtikon between the Linth plane and the Zürich highlands (Fig. 1). This glacier connected the Wehntal with an Alpine catchment mainly characterised by limestones and marls, yielding the high carbonate contents of the proglacial sediments. The maximum extent of this glacier remains unknown and would have been located somewhere between the Hombrechtikon threshold and the drill site of Niederweningen. As the age of the lacustrine sediment fill of Unit A covers most of MIS 6 (Fig. 9), it is rather unlikely that the glacier advanced beyond the drill site during this stage.

The average sedimentation rate of the entire unit is in the range of $0.2 \mathrm{~mm} \mathrm{a}^{-1}$, which is a very low value for such a proglacial lake environment, even in glacier-distal areas. Varve thicknesses (Fig. 6f) also suggest a much higher annual sedimentation rate of $\sim 1-10 \mathrm{~mm} \mathrm{a}^{-1}$; Unit A therefore is unlikely to represent a continuously deposited and complete sequence, and this is also supported by the presence of the above mentioned unconformity.

In the upper part of Unit A, a proglacial lake similar to the one below the unconformity became established, but carbonate content gradually decreases (Fig. 4). This potentially reflects the melting back of the glacier into the Alps, cutting off the carbonate supply from the lake's catchment. Towards the top of the unit, sediments contain more sandy layers that include reworked organic material, probably reflecting a gradually warmer climate. Just below the boundary to the overlying Unit B, the light-coloured silt deposits containing a lacustrine mollusc fauna and characean flora together with a typical «late glacial» palynoflora, document the transition into MIS 5 at $\sim 130 \mathrm{ka}$, when climate became significantly warmer and the lake became gradually shallower. Thin dark layers full of fine plant remains document the establishment of organic swampy areas nearby where the plant remains became reworked and deposited in this shoaling lake. Plant roots and bioturbation at the top of Unit A suggest a prograding shoreline. The contact to the overlying peat unit is extremely sharp and reflects a sudden lake level drop, which could have been caused by a moraine dam failure as known from similar environments (Blass et al. 2003; Strasser et al. 2008).

\section{Unit B: between $\sim 120$ and $\sim 110 \mathrm{ka}$ \\ (or alternatively between $\sim 120$ and $\sim 80 \mathrm{ka}$ )}

According to the age model and pollen data, the lower part of the peat interval of Unit B was deposited at the end of the Last Interglacial (late middle-late Eemian, MIS 5e) suggesting a hiatus of several thousand years (early-early middle Eemian) at its base. The unit starts above the erosive base with a thin layer containing abundant wood fragments, possibly deposited during a flood event in the context of the rapid lowering of the lake level. The runoff flood caused by such a lowering could have created the erosive power to remove a former older part of the peat and thus cause the observed hiatus. The upper part is a compact highly organic moss peat, which lacks detrital constituents. The presence of chironomid larvae and bryozoan statoblasts suggests deposition of nearly pure plant material in a swamp of a very shallow lake or pond ecosystem (written communication O. Heiri, Utrecht). Towards the top of the peat unit, characterised by Cyperaceae, the first layers of silt and sand reflect a gradual transition to the overlying inorganic sediments, and are likely the result of a stepwise increase in water level, which could have been caused by an increase in delivery of detrital sediment from a tributary clogging the outflow. These processes mark the transition into a wetter and eventually colder climate.

The palynologic vegetation sequence in Unit B is identical with the one already obtained from a previously completed drill hole nearby (Niederweningen II; Welten 1988). The remarkable presence of Abies in PZ NW-B1 reflects a warmer climate with high atmospheric humidity, while overlying Zone NW-B2, despite dense forests, indicates a more boreal environment with lower temperatures. Based on a comparison with the long sequences of Gondiswil (Wegmüller 1992) and Füramoos (Müller 2001) the correlation of PZ NW-B1 and NW-B2 with the end of the Eemian seems to be most likely. But contrary to the expected continuous climatic deterioration towards the end of the interglacial, environmental conditions improve in Zone NW-B3. Welten (1988) interpreted the corresponding sequence as an Early Würm interstadial. The presence of Osmunda underlines this correlation: Osmunda was rare during MIS 5e (Eemian; Grüger 1979; Drescher-Schneider 2000; Müller 2001), but became common in MIS 5c and in MIS 5a (Drescher-Schneider 2000; Müller 2001), making the stratigraphic time covered by Unit B much longer (e.g., upper boundary as young as $80 \mathrm{ka}$ ). In this case, however, it is hard to explain why the stadials MIS $5 \mathrm{~d}$ and MIS $5 \mathrm{~b}$ were not recorded in the sedimentary record. Alternatively, the «warming» of PZ NW-B3 could be explained by a not continuous climatic decline at the end of the Eemian that may have been characterised by several oscillations as shown at Mondsee (Drescher-Schneider 2000) so that Zone NW-B3 could represent one of the short climatic improvements before the very end of the Eemian. The large gap of IRSL/OSL ages below and above Unit B (Fig. 9; Table 1) cannot rule out either of these scenarios, and further investigations are required to solve this controversy. 
Unit C: between $\sim 110$ and $\sim 60 \mathrm{ka}$

(or alternatively between $\sim 80$ and $\sim 60 \mathrm{ka}$ )

The sediments of Unit $\mathrm{C}$ are similar to those of Unit A but lack the characteristic fine laminations typical for proglacial lakes and display much lower carbonate contents (10-20\%). Furthermore, no direct glacial influence or ice contact sediments are present. This implies that the lake was not directly connected to a glacier and, in contrast to Unit A, to the alpine carbonate-dominated catchment. Even if the catchment was not necessarily dominated by glacier influences, the lack of organic material and biogenic remains indicates deposition in a cold lake. The intercalations of silt and sand deposits in Unit $\mathrm{C}$ represent highenergy runoff events from the main tributary or from increased local deltaic sedimentation from the Lägeren hills. The increased runoff combined with increased detrital sediment load must have led to a clogging of the valley outflow, so that the base level slowly rose thus flooding the former peat deposits.

\section{Unit D: between $\sim 60$ and $\sim 40 \mathrm{ka}$}

The detrital lake sediments of Unit $\mathrm{C}$ are overlain by intercalations of lake sediments and dark organic-rich gyttia layers and a prominent, $50 \mathrm{~cm}$-thick gyttia at the top. The gyttia layers were either formed in situ and were caused by a rapidly fluctuating water level or, more likely, are reworked peat layers that were flushed into the lake during erosive flood events. In any case, these sediments document an increased organic productivity caused by a relatively warmer climate during MIS 3. The uppermost part of the equivalent «Mammoth peat» in the adjacent construction pit has been dated to $\sim 45 \mathrm{ka}$ (Hajdas et al. 2007; Preusser and Degering 2007) and is not as «pure» as the peat of Unit B below, as it received more detrital input during phases of high water-level. The study of pollen, wood and other plant material from the 80-100 cm thick peat horizon at the 2003 mammoth site (Drescher-Schneider et al. 2007; Furrer et al. 2007) suggests a long shoaling phase of a former Wehntal Lake, building swamps and marshes. In the lower part of the peat the amount of tree pollen was very low, interpreted as indicating unfavourable conditions for tree growth on the surrounding slopes (Drescher-Schneider et al. 2007). During the following period climate improved and the valley was partly covered by open forest tundra with Picea, Betula and Larix. The vegetation reconstructed for the middle part of the peat indicates marshes and wet meadows in an open flooded valley plain. The upper part with the embedded mammoth skeleton was an almost pure moss peat. At the top of the «Mammoth peat» at the construction pit in 2003 (Furrer et al. 2007), the pollen spectrum reflected the end of warmer climatic conditions.
The uppermost $25 \mathrm{~cm}$ of Unit D, consisting of silt and intercalated thin organic layers suggest a gradually increasing water level. The sediment succession was deposited during a colder and wetter climate phase encompassing the middle part of MIS 3. The spectacular deformation of the «Mammoth peat» and its under- and overlying silts, documented in construction pits of the years 1987, 2003 and 2004, reflect an important phase of cryoturbation (Schlüchter 1988b, 1994; Furrer et al. 2007). The age of this permafrost phenomenon is not dated, but belongs most probably to late MIS 3 and MIS 2 including the Last Glacial Maximum. No signs of direct glacial impact are visible, which is explained by the up-valley location of the LGM terminal moraine, which is well exposed $4 \mathrm{~km}$ ESE of Niederweningen (Fig. 2).

\section{Unit E and F: Late Glacial and Holocene}

The gravel, sand and silt of Unit E belong to a fluviatile fan, deposited by a local creek coming from the lateral Lägeren slope. The dominantly carbonate composition of the gravels and their matrix and the oxic brownish colors show that the source was not the main valley tributary but the lateral Lägeren anticline, where Late Jurassic limestone outcrops became eroded. Unit $\mathrm{F}$ is a mostly alluvial succession that formed the modern slopes and the marginal valley floor. Towards the top, modern soil formation led to organic-rich silt with abundant plant remains. This succession was deposited during a wet climate phase encompassing the latest part of the Pleistocene and/or the Early Holocene (late MIS 2 and/or early MIS 1).

\section{Conclusions}

The origin of the overdeepened basin of Wehntal is intriguing, since it extends well beyond the maximum glacial extent of the LGM. Obviously, an older and more extensive glaciation must have caused the glacial erosion that carved out the basin. The upper $30 \mathrm{~m}$ of the valley fill at the drill site, dated at the base to $\sim 170-180 \mathrm{ka}$ (early MIS 6), indicate that the MIS 6 glaciation is not a candidate for this process. The phase of erosion must be older than $180 \mathrm{ka}$ with MIS 8 being the youngest of the possible candidates $(\sim 260 \mathrm{ka})$.

Lithologic Unit A represents a thick and fairly homogenous succession of proglacial lake sediments. The laminated fine-grained inorganic particles with a high carbonate content document an Alpine glacier located up-valley that steadily fed this lake for quite some time (between $\sim 180$ and $130 \mathrm{ka}$ ). Sediment folding and faulting occurring around $140 \mathrm{ka}$ probably indicate either iceberg-ploughing or subglacial ice-contact deforming the lake sediments. 
Assuming that the sediment deformation observed in the drill cores did not occur subglacially, as indicated by the lack of coarse-grained sediments, the glacier did not apparently reach beyond the drill site and was most likely less extensive than the LGM.

The lacustrine phases of the Wehntal succession are interrupted by the two peat horizons, when water level was temporarily lowered. Below and above the peat of Unit B, the sedimentary succession shows no signs of fluvial deposition, although sandy layers with local detrital input, but still deposited in a lacustrine environment, increase upcore. The dual system of high-water levels during glacial dominance (proglacial or «cold» lacustrine sediments) and lower water-levels during warmer phases (peat deposits) requires a hydrologic control of the base level related to climate/glacier fluctuations. These changes could be caused (1) by high sediment-supply down-valley originating from lateral deltas or from slope instabilities, both of which could have clogged the outflow during cold times, (2) by damming from remaining terminal moraines rising the outflow level until they fail and collapse, or (3) by differential vertical movements caused by changing local isostatic conditions due to the weight of the large ice masses in the Alps. The intercalations between these two depositional end members, i.e. between lake and peat deposits, were only replaced in the latest Pleistocene, when eroding melt water from the advancing Linth-Glatt glacier transported alpine gravels through the Wehntal. These gravels cover the upper part of the Wehntal; in the lower part they are limited to a channel in the axis and the northern side of the valley. In the area of Niederweningen, the southern side of the valley was flooded by detrital alluvial deposits from a lateral creek (Unit E and F). The axial plain of the Wehntal was still dominated by swamp deposits during the Holocene, until the artificial deepening of the Surb creek during the Second World War for agronomic melioration.

Further research is needed in order to solve some of the remaining questions. This requires more drill holes at key locations that may provide the clues to issues such as the age of erosion leading to the overdeepened troughs or the exact maximum extension of the MIS 6 glaciers in the Swiss lowlands.

Acknowledgments We thank H. Mayrhofer, the director of the Institute of Plant Sciences of Karl-Franzens-Univerity Graz, for supporting the preparation of the pollen samples in his laboratory. A. Gilli supported analysis in the Limnogeology Laboratory of the ETHZ. O. Heiri and W. Schoch contributed important data and interpretations on chironomids and wood remains, respectively. We acknowledge financial and operational support from the Foundation Mammutmuseum Niederweningen (R. Hauser, F. Wittwer). S. Lowick is financially supported by Swiss National Science Foundation through project grants 200021-107820 and 200020-121671. The authors are grateful to Barbara Wohlfarth and Dietrich Ellwanger for their constructive reviews of the manuscript.

\section{References}

Anselmetti, F. S., Bühler, R., Finger, D., Girardclos, S., Lancini, A., Rellstab, C., et al. (2007). Effects of Alpine hydropower dams on particle transport and lacustrine sedimentation. Aquatic Sciences, 69, 179-198.

Bassinot, F. C., Labeyrie, L. D., Vincent, E., Quidelleur, X., Shackleton, N. J., \& Lancelot, Y. (1994). The astronomical theory of climate and the age of Brunhes-Matuyama magnetic reversal. Earth and Planetary Science Letters, 126, 91-108.

Beaulieu, J.-L., de Andrieu-Ponel, V., Reille, M., Grüger, E., Tzedakis, C., \& Svoboda, H. (2001). An attempt at correlation between the Velay pollen sequence and the Middle Pleistocene stratigraphy from central Europe. Quaternary Science Reviews, 20, 1593-1602.

Birks, H. J. B. (1973). Past and present vegetation of the Isle of Skye-a palaeoecological study (p. 415). London: Cambridge University Press.

Bitterli-Dreher, P., Graf, H.R., Naef, H., Diebold, P., Matousek, F., Burger, H. \& Pauli-Gabi, T. (2007). Geologischer Atlas der Schweiz 1:25,000. Blatt 1070 Baden mit Erläuterungen. Bundesamt für Landestopografie swisstopo, $152 \mathrm{~S}$.

Blass, A., Anselmetti, F. S. \& Ariztegui, D. (2003). 60 years of glaciolacustrine sedimentation in Steinsee (Sustenpass, Switzerland) compared with historic events and instrumental meteorological data. Eclogae geologicae Helvetiae 96, Supplement $1,59-71$.

Coope, G. R. (2007). Coleoptera from the 2003 excavations of the mammoth skeleton at Niederweningen, Switzerland. Quaternary International, 164-165, 130-138.

Drescher-Schneider, R. (2000). Die Vegetations- und Klimaentwicklung im Riß/Würm-Interglazial und im Früh- und Mittelwürm in der Umgebung von Mondsee. Ergebnisse der pollenanlytischen Untersuchungen. In D. van Husen (Ed.), Klimaentwicklung im Riss/Würm Interglazial (Eem) und Frühwürm (Sauerstoffisotopenstufe 6-3) in den Ostalpen. Mitteilungen der Kommission für Quartärforschung Österreichischen Akademie der Wissenschaften 12, 39-92.

Drescher-Schneider, R., Jacquat, C., \& Schoch, W. (2007). Palaeobotanical investigations of the mammoth site of Niederweningen (Kanton Zürich), Switzerland. Quaternary International, 164-165, 113-129.

Eyles, N., Eyles, C. H., Woodworth-Lynas, C., \& Randall, T. A. (2005). The sedimentary record of drifting ice (early Wisconsin Sunnybrook deposit) in an ancestral ice-dammed Lake Ontario, Canada. Quaternary Research, 63, 171-181.

Furrer, H., Graf, H. R., \& Mäder, A. (2007). The mammoth site of Niederweningen, Switzerland. Quaternary International, 164-165, 85-97.

Geyh, M. A., \& Müller, H. (2005). Numerical Th-230/U dating and a palynological review of the Holsteinian/Hoxnian Interglacial. Quaternary Science Reviews, 24, 1861-1872.

Grüger, E. (1979). Spätriss, Riss/Würm und Frühwürm am Samerberg in Oberbayern-ein vegetationsgeschichtlicher Beitrag zur Gliederung des Jungpleistozäns. Geologica Bavarica, 80, 5-64.

Habbe, K. A., Ellwanger, D., \& Becker-Haumann, R. (2007). Stratigraphische Begriffe für das Quartär des süddeutschen Alpenvorlandes. Eiszeitalter und Gegenwart (Quaternary Science Journal), 56, 66-83.

Hajdas, I., Bonani, G., Furrer, H., Mäder, A., \& Schoch, W. (2007). Radiocarbon chronology of the mammoth site at Niederweningen, Switzerland: Results from dating bones, teeth, wood, and peat. Quaternary International, 164-165, 98-105.

Hajdas, I., Michczyński, A., Bonani, G., Wacker, A., \& Furrer, H. (2009). Dating bones near the limit of the radiocarbon dating 
method: study case mammoth from Niederweningen, ZH. Radiocarbon, 51, 675-680.

Jordan, P., Schwab, M., \& Schuler, T. (2008). Digitales Höhenmodell-Am Beispiel der Felsoberfläche der Nordschweiz. GWA, 8, 443-449.

Keller, O., \& Krayss, E. (1999). Quartär und Landschaftgenese. Mitteilungen der Thurgauischen Naturforschenden Gesellschaft, 55, 39-67.

Kulig, G. (2005). Erstellung einer Auswertesoftware zur Altersbestimmung mittels Lumineszenzverfahren unter spezieller Berücksichtigung des Einflusses radioaktiver Ungleichgewichte in der ${ }^{238} \mathrm{U}$-Zerfallsreihe. Unpublished BSc thesis, Technical University Bergakademie Freiberg.

Litt, T., Behre, K.-E., Meyer, K.-D., Stephan, H.-J., \& Wansa, S. (2007). Stratigraphische Begriffe für das Quartär des norddeutschen Vereisungsgebietes. Eiszeitalter \& Gegenwart (Quaternary Science Journal), 56, 7-65.

Lowick, S. E., \& Preusser, F. (2009). A method for retrospectively calculating water content for desiccated core samples. Ancient $T L, 27,9-13$.

Maltman, A.J., Hubbard, B. \& Hambrey, M.J. (Eds.) (2000). Deformation of Glacial Materials (377 pp). Geological Society Special Publication 176. Bath: The Geological Society of London.

Mauz, B., \& Lang, A. (2004). Removal of the feldspar-derived luminescence component from polymineral fine silt samples for optical dating applications: evaluation of chemical treatment protocols and quality control procedures. Ancient $T L, 22,1-8$.

Müller, U. (2001). Die Vegetations- und Klimaentwicklung im jüngeren Quartär anhand ausgewählter Profile aus dem südwestdeutschen Alpenvorland. Tübinger Geowissenschaftliche Arbeiten D7, 118 pp.

Murray, A. S., \& Wintle, A. G. (2000). Luminescence dating of quartz using an improved single-aliquot regenerative-dose protocol. Radiation Measurements, 32, 57-73.

Murray, A. S., \& Wintle, A. G. (2003). The single aliquot regenerative dose protocol: potential for improvements in reliability. Radiation Measurements, 37, 377-381.

Preusser, F. (2003). IRSL dating of K-rich feldspars using the SAR protocol: Comparison with independent age control. Ancient TL, $21,17-23$.

Preusser, F. (2004). Towards a chronology of the Late Pleistocene in the northern Alpine Foreland. Boreas, 33, 195-210.

Preusser, F., \& Degering, D. (2007). Luminescence dating of the Niederweningen mammoth site, Switzerland. Quaternary International, 164-165, 106-112.

Preusser, F., Degering, D., Fuchs, M., Hilgers, A., Kadereit, A., Klasen, N., et al. (2008). Luminescence dating: Basics, methods and applications. Eiszeitalter \& Gegenwart (Quaternary Science Journal), 57, 95-149.

Preusser, F., Drescher-Schneider, R., Fiebig, M., \& Schlüchter, Ch. (2005). Re-interpretation of the Meikirch pollen record, Swiss Alpine Foreland, and implications for Middle Pleistocene chronostratigraphy. Journal of Quaternary Science, 20, 607-620.

Preusser, F., \& Kasper, H. U. (2001). Comparison of dose rate determination using high-resolution gamma spectrometry and inductively coupled plasma-mass spectrometry. Ancient $T L$, 19, 19-23.
Schindler, C. (1985). Geologisch-geotechnische Verhältnisse in Schaffhausen und Umgebung. Beiträge zur Geologie der Schweiz - Kleinere Mitteilungen, 74, 199.

Schlüchter, Ch. (1979). Übertiefte Talabschnitte im Berner Mittelland zwischen Alpen und Jura (Schweiz). Eiszeitalter und Gegenwart, 29, 101-113.

Schlüchter, Ch. (1988a). A non-classical summary of the Quaternary stratigraphy of the northern Alpine Foreland of Switzerland. Bulletin de la Société neuchâteloise de Géographie, 32(33), 143-157.

Schlüchter, Ch. (1988b). Neue geologische Beobachtungen bei der Mammutfundstelle Niederweningen (Kt. Zürich). Vierteljahresschrift der naturforschenden Gesellschaft Zürich, 133, 99-108.

Schlüchter, Ch. (1989a). Thalgut: ein umfassendes eiszeitstratigraphisches Referenzprofil im nördlichen Alpenvorland. Eclogae Geologicae Helvetiae, 82, 277-284.

Schlüchter, Ch. (1989b). The most complete Quaternary record of the Swiss Alpine Foreland. Palaeogeography, Palaeoclimatology, Palaeoecology, 72, 141-146.

Schlüchter, Ch. (1994). Das Wehntal-Eine Schlüsselregion der Eiszeitenforschung. Jahrheft des Zürcher Unterländer Museumsvereins, 28(1994/95), 4-24.

Strasser, M., Schindler, C., \& Anselmetti, F. S. (2008). Late Pleistocene earthquake-triggered moraine dam failure and outburst of Lake Zurich: Switzerland. Journal of Geophysal Research, 113, F02003. doi:10.1029/2007JF000802.

Strasser, M., Stegmann, S., Bussmann, F., Anselmetti, F. S., Rick, B., \& Kopf, A. (2007). Quantifying subaqueous slope stability during seismic shaking: Lake Lucerne as model for ocean margins. Marine Geology, 240, 77-97.

Tütken, T., Furrer, H., \& Vennemann, T. W. (2007). Stable isotope compositions of mammoth teeth from Niederweningen, Switzerland: Implications for the Late Pleistocene climate, environment and diet. Quaternary International, 164-165, $139-150$.

Wallinga, J., Murray, A., \& Wintle, A. (2000). The single-aliquot regenerative-dose (SAR) protocol applied to coarse-grain feldspar. Radiation Measurements, 32, 529-533.

Wegmüller, S. (1992). Vegetationsgeschichtliche und stratigraphische Untersuchungen an Schieferkohlen des nördlichen Alpenvorlandes. Denkschriften der Schweizerischen Akademie der Naturwissenschaften, 102, 82.

Welten, M. (1982). Pollenanalytische Untersuchungen im Jüngeren Quartär des nördlichen Alpenvorlandes der Schweiz. Beiträge zur Geologischen Karte der Schweiz-Neue Folge, 156, 174.

Welten, M. (1988). Neue pollenanalytische Ergebnisse über das Jüngere Quartär des nördlichen Alpenvorlandes der Schweiz (Mittel- und Jungpleistozän). Beiträge zur geologischen Karte der Schweiz-Neue Folge, 162, 40.

Wintle, A. G., \& Murray, A. S. (2006). A review of quartz optically stimulated luminescence characteristics and their relevance in single-aliquot regeneration dating protocols. Radiation Measurements, 41, 369-391.

Zander, A., Degering, D., Preusser, F., \& Brückner, H. (2007). Optically stimulated luminescence dating of sublittoral and intertidal sediments from Dubai, UAE: Radioactive disequilibria in the uranium decay series. Quaternary Geochronology, 2, $123-128$. 